Int. J. Electrochem. Sci., 15 (2020) 5477 - 5486

\title{
The Performance of Molecularly Imprinted Polymers (MIPs) - Modified Carbon Paste Electrode and Its Application in Detecting Phenol
}

\author{
Henry Setiyanto ${ }^{1, *}$, Sri Rahmadhani ${ }^{1}$, Sukandar Sukandar ${ }^{2}$, Vienna Saraswaty, \\ Muhammad Ali Zulfikar ${ }^{l}$, Nandang Mufti ${ }^{4}$ \\ ${ }^{1}$ Analytical Chemistry Research Group, Institut Teknologi Bandung, Bandung, Indonesia \\ ${ }^{2}$ Waste and Air Management Research Group, Institut Teknologi Bandung, Bandung, Indonesia \\ ${ }^{3}$ Research Unit for Clean Technology, Indonesian Institute of Sciences, Bandung, Indonesia \\ ${ }^{4}$ Department of Physics, Universitas Negeri Malang, Malang, Indonesia \\ *E-mail: henry@chem.itb.ac.id
}

doi: $10.20964 / 2020.06 .66$

Received: 24 February 2020 / Accepted: 9 April 2020 / Published: 10 May 2020

Phenol is a very important chemical compound in life, especially in industry. Various methods of phenol analysis have been developed due to the harmful effect of phenol wastes that pollute the waters. A method employed to analyze phenol with simple instrumentation having good selectivity and sensitivity was a potentiometric method, which used a carbon paste electrode as the working electrode and was modified with a molecularly imprinted polymers (MIPs). The carbon paste electrode was electrochemically modified using a 15-cycle cyclic voltammetry technique at a potential range of $-0.2 \mathrm{~V}$ - $1.0 \mathrm{~V}$ and scan rate of $100 \mathrm{mV} / \mathrm{s}$ with composition of the solution being $0.1 \mathrm{mM}$ phenol: $0.2 \mathrm{mM}$ aniline in a buffer solution having $\mathrm{pH}$ value of 9 and $0.1 \mathrm{M} \mathrm{KCl}$ as supporting electrolyte. Phenol was extracted from the polymer matrix electrochemically using $0.1 \mathrm{M} \mathrm{HCl}$, thus expecting to form templates that can specifically recognize the molecule. The results showed that the phenolic content analysis, via a potentiometric method using MIPs-modified carbon paste electrode, had a linear range of $10^{-7} \mathrm{M}-10^{-}$ ${ }^{1} \mathrm{M}$ with a detection limit of $2.5 \times 10^{-7} \mathrm{M}$. Besides, this electrode can respond to analytes within $60-70$ $\mathrm{s}$. The accuracy was determined based on the relative error value ( $\% \mathrm{Er})$. The $\%$ Er obtained ranged from $1 \%$ to $3 \%$, indicating that this method is quite accurate for the determination of phenol. The precision was identified with a good coefficient of variation, which was less than $2 \%$. The effect of interference compounds was observed in the small selectivity coefficient $\left(K_{A, B}^{\text {pot }}<1\right)$, thus inferring that these electrodes have a higher selectivity towards phenol than other compounds contained in the sample. As a comparison, phenol measurements were carried out using the UV-Vis spectrophotometric method. Based on the percent recovery value and t-test, where $t_{\text {table }} 4.30>t_{\exp } 1.12$, it can be concluded that measurement with a potentiometric method using MIPs-modified carbon paste working electrode has no significant difference compared to the UV-Vis spectrophotometric method. 
Keywords: electrochemistry, potentiometry, molecularly imprinted polymers (MIPs), polyaniline, phenol.

\section{$\underline{\text { FULL TEXT }}$}

(C) 2020 The Authors. Published by ESG (www.electrochemsci.org). This article is an open access article distributed under the terms and conditions of the Creative Commons Attribution license (http://creativecommons.org/licenses/by/4.0/). 